\title{
Characterization of bentonite clays from Cubati, Paraíba (Northeast of Brazil)
}

\section{(Caracterização de argilas bentoníticas de Cubati, Paraíba - nordeste do Brasil)}

\author{
C.I.R. de Oliveira' ${ }^{1}$ M. C. G. Rocha ${ }^{1}$, A. L. N. da Silva ${ }^{2}$, L.C.Bertolino ${ }^{3, *}$ \\ ${ }^{I}$ Instituto Politécnico, Universidade do Estado do Rio de Janeiro, R. Bonfim 25, Bloco 1, RJ, Brazil 28625-570 \\ ${ }^{2}$ Instituto de Macromoléculas Professora Eloisa Mano, Universidade Federal do Rio de Janeiro, \\ Centro de Tecnologia, Bloco J, Rio de Janeiro, RJ, Brazil 21945-970 \\ ${ }^{3}$ Centro de Tecnologia Mineral, Ministério da Ciência, Tecnologia e Inovação, Av. Pedro Calmon, 900, \\ Rio de Janeiro, RJ, Brazil 21941-908 \\ *lcbertolino@cetem.gov.br
}

\begin{abstract}
Clays of different composition have been used in the development of polymer nanocomposites. The utilization of bentonite clays of the State of Paraíba, Brazil, has been emphasized mainly due to their availability. However, these bentonite deposits are becoming exhausted after several years of exploitation. Thus, the aim of this work was to characterize bentonite clays recently discovered in the municipality of Cubati, Paraíba. The samples underwent a particle size classification step and were characterized by granulometric analysis by laser diffraction, X-ray fluorescence, X-ray diffraction, infrared spectroscopy, thermogravimetric analysis and cation exchange capacity. The results of particle size distribution showed that the clay samples have similar physical characteristics to bentonite clays of Boa Vista, Paraíba. Results of X-ray diffraction indicated that the mineralogical composition of the samples consisted of montmorillonite, kaolinite and quartz. The characterization of the samples by FTIR confirmed these results. Results of chemical analysis showed that the samples are polycationic bentonite clays and have predominantly different exchangeable cations similar to those seen in South American bentonites.
\end{abstract}

Keywords: clay, bentonite, Cubati, characterization, polymer nanocomposites.

Resumo

Argilas de diferentes composições têm sido usadas no desenvolvimento de nanocompósitos poliméricos. Argilas bentoníticas do estado da Paraíba, Brasil, vêm sendo muito utilizadas devido, principalmente, a sua disponibilidade. No entanto, os depósitos dessas argilas têm mostrado uma exaustão após diversos anos de intensa exploração. Logo, o principal objetivo do presente trabalho foi caracterizar argilas bentoníticas recentemente descobertas no município de Cubati, Paraíba. As amostras passaram por uma etapa de classificação de tamanho de partícula e foram caracterizadas por análise granulométrica por difração a laser, fluorescência de raios X, difração de raios X, espectroscopia de absorção no infravermelho, análise termogravimétrica e capacidade de troca catiônica. Os resultados da distribuição de tamanho de partícula mostraram que as amostras das argilas têm características físicas similares às argilas bentoníticas de Boa Vista, Paraíba. Resultados de difração de raios X indicaram que a composição mineralógica das amostras é constituída por montmorilonita, caulinita e quartzo. A caracterização das amostras por espectroscopia de absorção no infravermelho confirmou esses resultados. Resultados da análise química mostraram que as amostras são argilas bentoníticas policationicas e que apresentam, predominantemente, diferentes cátions trocáveis similares aos encontrados em bentonitas sul-americanas.

Palavras-chave: bentonita, Cubati, caracterização, nanocompósitos poliméricos.

\section{INTRODUCTION}

In recent years, polymer nanocomposites have received considerable attention in the academia and industry due to a significant improvement in the properties of these materials, when compared to the properties of pure polymers or conventional composites [1]. These improvements include increase in some properties, such as: mechanical and thermal properties, reduced permeability to gases, etc. [2].
Polymer nanocomposites comprise a class of materials formed by adding a small quantity by weight of inorganic filler $(<5 \%)$, mainly clays, which are finely dispersed in a polymeric matrix in nanometer scale [3,4]. This class of materials began to be studied in the 80 s by Toyota Research Laboratory with the development of nanocomposites of polyamide and clay [5].

Natural layered silicates such as montmorillonite (MMT), which is the main constituent of the mineral bentonite clays, 
are inorganic fillers commonly used for preparing polymeric nanocomposites [6]. Bentonite rocks are composed essentially of one or more of the group of smectite clay minerals (montmorillonite itself, beidelite, nontronite, saponite, sauconite, volconscoite and hectorite), formed by devitrification and subsequent chemical alteration of a glassy material of igneous origin, usually a tuff or volcanic ash, acid preferably [7]. Technologically, there is a consensus that if smectite clays present similar characteristics or industrial applications to those presented by natural bentonites, they can be called bentonites regardless of their geological origin [7]. The properties of bentonite clays depend on the structure and chemical composition, exchangeable ion type and small particle size of smectites. These properties include large specific surface area, high cation exchange capacity and others physical-chemical properties, such as: swelling, plasticity, cohesion, compressibility, strength, particle size, adsorptive properties, pore structure, surface acidity, and catalytic activity $[8,9]$.

Bentonite is an aluminosilicate 2:1 which in its natural form has the exchangeable cations $\mathrm{Na}^{+}, \mathrm{Mg}^{2+}, \mathrm{Ca}^{2+}, \mathrm{Al}^{3+}$ and $\mathrm{Fe}^{3+}$. In Brazil, the most common form of its occurrence is as polycationic bentonite [10]. Most Brazilian bentonite reserves, about $62 \%$ are located in the state of Paraíba, northeast of Brazil, mainly in the municipality of Boa Vista. Discovered in the early 60's, these deposits have been intensively studied. These studies resulted in their use in a wide range of technological applications. However, the random exploration of these deposits for many years is causing the depletion of these clays, which may cause a serious problem to the national industry. In order to circumvent this problem, studies have been performed in order to improve the properties of other clays from Paraíba, which have not been often used due to their poor properties. With the same purpose, research activities have been carried out aiming to discover new occurrences with similar or superior properties to those presented by the already exploited clays.

There are many published studies on the application of clays from the municipality of Boa Vista, especially in the field of nanocomposites [11-15]. However, there is a lack of studies on clays from other regions of Paraíba. Most of characterization studies of bentonite clays from these regions intend to develop materials for using in water based drilling fluids [16-21]. In a recent work, Menezes et al. [21] performed the physical and mineralogical characterization of bentonite clays from the municipality of Cubati, Paraíba. In this case, the study was developed with the objective of finding applications of these materials in different industrial sectors [21]. The aim of this work was to study the characterization of new occurrences of bentonite clays in the municipality of Cubati, Paraíba, in order to assess the possibility of their application in polymer nanocomposites.

\section{MATERIALS AND METHODS}

Materials: in this study, clay samples were collected in the mines fronts in the region of Cubati, Paraíba, Brazil. The clay samples were identified according to its source as JG and RF clays. The RF clay was collected in the geographical coordinates 24M 07997429244916 while the JG clay in the geographical coordinates 24M 0799950 9245922. The methylene blue and sodium chloride were provided by Proquimios (Rio de Janeiro, RJ). Sulfuric acid was provided by Vetec Química Fina Ltda. (Rio de Janeiro, $\mathrm{RJ})$.

Clays preparation: the particle size separation of the clay was performed by the wet sieving method. Samples were dispersed in distilled water and then passed through sieves (Granutest) of $0.053,0.044$ and $0.022 \mathrm{~mm}$. The clay fraction with size less than $0.022 \mathrm{~mm}$ was separated, dried in an oven at $60{ }^{\circ} \mathrm{C}$ and milled providing a homogeneous sample. This fraction was used in the characterization of clays.

Clays characterization: the clays were characterized using the following techniques: multiangle laser light scattering (MALLS), X-ray fluorescence (XRF), X-ray diffraction (XRD), Fourier transform infrared spectroscopy (FTIR), thermogravimetric analysis (TGA), and cation exchange capacity (CEC).

Determination of particle size distribution of clays by MALLS: using a Mastersizer Hydro 2000SM equipment from Malvern Instruments. A small amount of sample was added to a beaker containing approximately $500 \mathrm{~mL}$ of deionized water with stirring at $1700 \mathrm{rpm}$. The dispersion was then homogenized by ultrasound application for $5 \mathrm{~min}$. Subsequently the samples were submitted to the laser light scattering.

Mineralogical analyses of the clays by XRD: the test was conducted in powder samples using a Bruker-D4 Endeavor equipment, with the following operating conditions: $\mathrm{Co}-\mathrm{K} \alpha, 40 \mathrm{kV}$ voltage and $40 \mathrm{~mA}$ current, $0.02^{\circ}$ step size, counting time/step of $0.5 \mathrm{~s}$ and a scanning angle $2 \theta$ from 4 to $80^{\circ}$. The qualitative interpretation of the XRD patterns were made by comparison with standards contained in the database PDF02 (ICDD, 2006), in BrukerDiffrac ${ }^{\text {Plus }}$ software.

Determination of the chemical composition of the clays by XRF: in a WDX fluorescence spectrometer, AXIOS (Panalytical). The semi-quantitative results were calculated as oxides and normalized to $100 \%$. The loss on ignition (LOI) was determined according to $\mathrm{LOI}=\left(\mathrm{W}_{\mathrm{d}}-\mathrm{W}_{\mathrm{f}}\right) / \mathrm{W}_{\mathrm{d}} \times 100$, where $\mathrm{W}_{\mathrm{d}}$ is the weight of the dry sample at $110^{\circ} \mathrm{C}$, and $\mathrm{W}_{\mathrm{f}}$ is the weight of the calcined sample at $1000^{\circ} \mathrm{C}$ during $3 \mathrm{~h}$.

Structural analyses of the clays by FTIR: performed using a Varian Spectrometer, Excalibur 3100. The spectra were obtained from 4000 to $400 \mathrm{~cm}^{-1}$ range, with samples pressed with $\mathrm{KBr}$ powder.

Evaluation of thermal stability of the clays by TGA: using a TA Instruments, Q500. The analyses were performed under nitrogen flow and the samples were heated from 30 a $700{ }^{\circ} \mathrm{C}$, at a heating rate of $10{ }^{\circ} \mathrm{C} / \mathrm{min}$.

Determination of CEC of the clays: using the methylene blue method based on the ASTM C837-09 standard [22]. 


\section{RESULTS AND DISCUSSION}

\section{Particle size distribution of clays}

Fig. 1a shows that both clays present wide particle size distributions. JG clay presents an average particle size of about $6.08 \mu \mathrm{m}$, while the average particle size of RF clay is about $5.33 \mu \mathrm{m}$. Fig. 1a also shows that the distribution curve for both samples is monomodal. The curves show a concentration of particles with size between 4 and $8 \mu \mathrm{m}$ for RF clay and between 5 and $9 \mu \mathrm{m}$ for JG clay. The specific surface area of the RF clay was about $1.63 \mathrm{~m}^{2} / \mathrm{g}$ while specific surface area of the JG clay was about $1.36 \mathrm{~m}^{2} / \mathrm{g}$. Fig. 1b shows that the content of clay fraction (diameter smaller than $2 \mu \mathrm{m}$ ) was about $10.13 \%$ for JG clay, whereas $14.81 \%$ for RF clay. In terms of accumulated volume of silt (particles with diameter between 2 and $20 \mu \mathrm{m}$ ), the samples showed high values of $86.22 \%$ and $82.44 \%$ for JG and RF clays, respectively. JG and RF clays present relatively low amounts of sand fraction, $3.65 \%$ and $2.75 \%$, respectively. The sand fraction is associated with particles with diameters above $20 \mu \mathrm{m}$. The results of particle size analysis of the
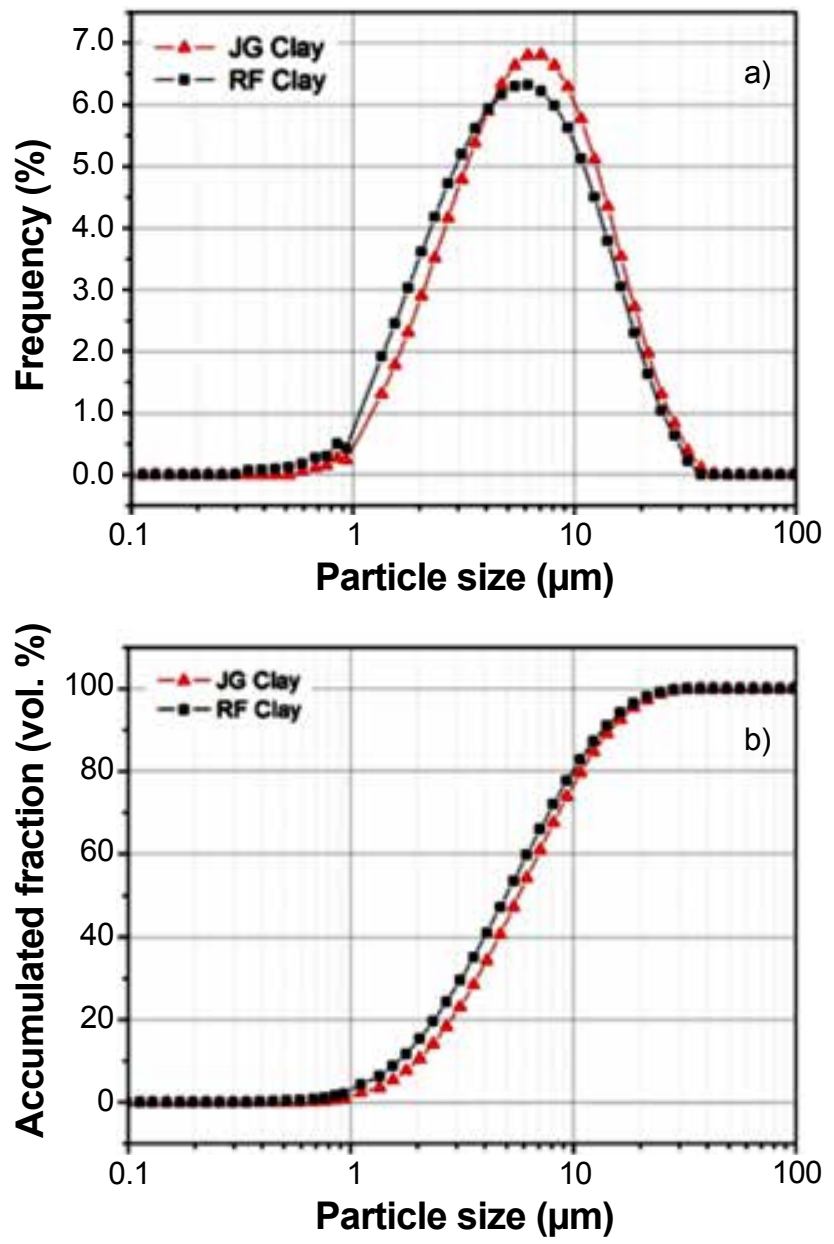

Figure 1: Particle size distribution curves of the studied clays: (a) histogram; (b) accumulated fraction.

[Figura 1: Curvas de distribuição de tamanho de partícula das argilas estudadas: (a) histograma; (b) fração acumulada.]
Table I - Particle size distribution and average particle diameter of the clays from Cubati, PB.

[Tabela I - Distribuição de tamanho de partícula e diâmetro médio de partícula das argilas de Cubati, PB.]

Clay Silt Sand Mean

Sample $(\mathrm{x}<2 \mu \mathrm{m}) \quad(2<\mathrm{x}<20 \mu \mathrm{m})(\mathrm{x}>20 \mu \mathrm{m})$ diameter

\begin{tabular}{lcccc} 
& $(\%)$ & $(\%)$ & $(\%)$ & $(\mu \mathrm{m})$ \\
\hline JG clay & 10.13 & 86.22 & 3.65 & 6.08 \\
RF clay & 14.81 & 82.44 & 2.75 & 5.33 \\
\hline
\end{tabular}

clay samples are summarized in Table I. Costa et al. [18] evaluated two bentonites clays from Cubati, Paraíba. The results of particle size distribution observed by the authors are very similar to those obtained for JG and RF clays in this study, indicating that these clays have similar physical characteristics of the bentonite clays of Paraíba [18].

\section{X-ray diffraction (XRD) of clays}

The characterization of the clay samples by XRD aimed to verify the existence of associated minerals and clay minerals. Fig. 2 presents the X-ray diffraction results of the clay samples studied in the present work. The XRD patterns show the presence of montmorillonite $(6.7,23.21,42.08$ and $\left.73.82^{\circ}\right)$ and kaolinite $(14.42,29.05,40.90,44.07,59.94$ and $\left.65.06^{\circ}\right)$ as majority phases. Leite et al. [23] characterized bentonite clay from Campina Grande, Paraíba, through XRD. The patterns showed the presence of diffraction peaks corresponding to planes (001) and (020), confirming the presence of montmorillonite in the samples. The data also showed the presence of impurities such as kaolinite (11.73 and $\left.23.45^{\circ}\right)$ and quartz $\left(20.87\right.$ and $\left.26.67^{\circ}\right)$ in bentonite clay evaluated [23]. In the XRD patterns of the clays obtained in

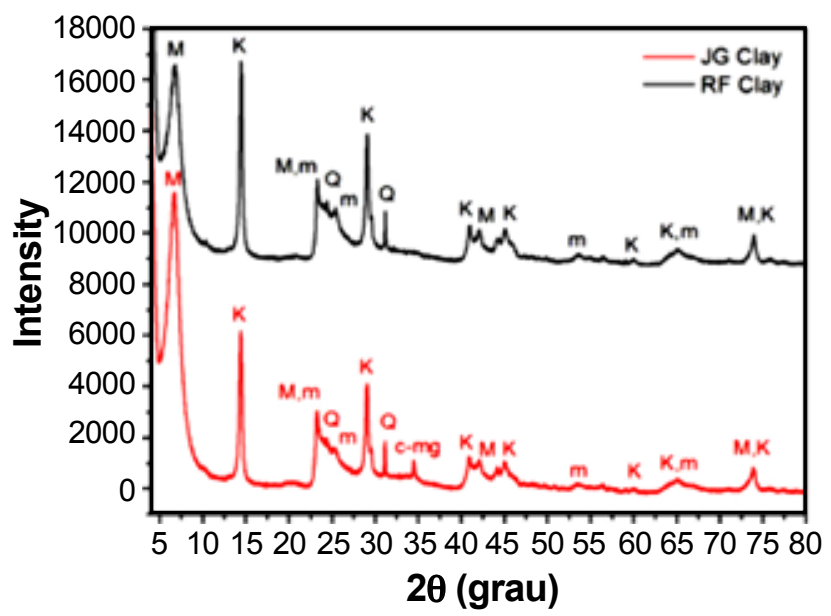

Figure 2: X-ray diffraction patterns of the studied clays [M montmorillonite (pdf 00-013-0135), K - kaolinite (pdf 01-0800886), Q - quartz (pdf 01-078-2315), m - muscovite (pdf 01-0820576), c-mg - calcite-magnesite (pdf 01-086-2335)].

[Figura 2: Difratogramas de raios $X$ das argilas estudadas [M - montmorilonita (pdf 00-013-0135), K - caulinita (pdf 01-0800886), $Q$ - quartzo (pdf 01-078-2315), $m$ - muscovita (pdf 01-0820576), c-mg - calcita-magnesita (pdf 01-086-2335)].] 
this study, the presence of quartz and muscovite was also observed. The JG clay shows traces of calcite-magnesite as indicated by the presence of a diffraction peak in $34.45^{\circ}$ (Fig. 2). Similar XRD results were obtained by Silva et al. [19] when they performed the characterization of bentonite clays from the municipality of Pedra Lavada, Paraíba.

\section{$X$-ray fluorescence (XRF) of clays}

Table II presents the results of chemical analysis obtained by XRF of the clay samples evaluated after sieving with a $0.022 \mathrm{~mm}$ sieve. The analysis of the results in Table II indicates that $\mathrm{SiO}_{2}$ and $\mathrm{Al}_{2} \mathrm{O}_{3}$ are the main components present in the clay samples. The $\mathrm{SiO}_{2}$ and $\mathrm{Al}_{2} \mathrm{O}_{3}$ contents were $47.3 \%$ and $28 \%$ for the JG clay and $49.9 \%$ and $31 \%$ for the RF clay, respectively. Similar values of these oxides were observed in the characterization by chemical analysis of bentonite clays from the municipality of Pedra Lavada, PB [19]. In Table II, the $\mathrm{SiO}_{2} / \mathrm{Al}_{2} \mathrm{O}_{3}$ ratio is also shown. Both clays present high amount of $\mathrm{SiO}_{2}$ and low amount of $\mathrm{Al}_{2} \mathrm{O}_{3}$. The $\mathrm{SiO}_{2} / \mathrm{Al}_{2} \mathrm{O}_{3}$ ratio was equivalent to 1.69 for the JG clay and 1.61 for the RF clay.

Table II - Chemical composition of the clays from Cubati, PB. [Tabela II - Composição química das argilas de Cubati, PB.]

\begin{tabular}{ccc}
\hline Oxide & JG clay $(\%)$ & RF clay $(\%)$ \\
\hline $\mathrm{SiO}_{2}$ & 47.30 & 49.90 \\
$\mathrm{Al}_{2} \mathrm{O}_{3}$ & 28.00 & 31.00 \\
$\mathrm{Na}_{2} \mathrm{O}$ & 0.62 & 0.60 \\
$\mathrm{MgO}$ & 1.70 & 1.10 \\
$\mathrm{P}_{2} \mathrm{O}_{5}$ & 0.04 & 0.02 \\
$\mathrm{SO}_{3}$ & 0.08 & 0.05 \\
$\mathrm{~K}_{2} \mathrm{O}$ & 0.31 & 0.31 \\
$\mathrm{CaO}$ & 3.70 & 0.46 \\
$\mathrm{TiO}_{2}$ & 0.94 & 1.05 \\
$\mathrm{Cr}_{2} \mathrm{O}_{3}$ & 0.02 & 0.02 \\
$\mathrm{MnO}$ & 0.10 & 0.01 \\
$\mathrm{Fe}_{2} \mathrm{O}_{3}$ & 3.80 & 3.10 \\
$\mathrm{SiO}_{2} / \mathrm{Al}_{2} \mathrm{O}_{3}$ & 1.69 & 1.61 \\
LOI & 13.42 & 12.43 \\
\hline LOI-weight loss-on-ignition. & &
\end{tabular}

LOI-weight loss-on-ignition.

The results indicate that the studied clays have high amount of clay minerals, mainly kaolinite and montmorillonite according to XRD results (Fig. 2). The JG and RF clays presented $3.8 \%$ and $3.1 \%$ of $\mathrm{Fe}_{2} \mathrm{O}_{3}$ content, respectively. Bentonite clays from the municipality of Boa Vista, PB, generally show $\mathrm{Fe}_{2} \mathrm{O}_{3}$ contents above $7 \%$. Nevertheless, the chemical compositions of bentonite usually vary because of the many substitutions are isomorphic in smectite, and because of the associated impurities (accessory minerals) [24]. With regard to other components, the clays showed similar levels of $\mathrm{Na}_{2} \mathrm{O}, \mathrm{K}_{2} \mathrm{O}, \mathrm{MgO}$ and $\mathrm{TiO}_{2}$ (Table II). According to [21], the oxides contents found are similar to those seen in South
American bentonites. The $\mathrm{CaO}$ content observed for JG clay was about $3.7 \%$, whereas only $0.46 \%$ was observed in the $\mathrm{RF}$ clay. This result is in agreement with the results observed with the X-ray diffraction. The XRD pattern of the JG clay (Fig. 2) shows the presence of a diffraction peak at $34.45^{\circ}$, which maybe attributed to the presence of calcite-magnesite. This diffraction peak is not observed in the XRD pattern of $\mathrm{RF}$ clay. The values of loss on ignition (LOI) of the clays are relatively high, and are very close. According to [25], the loss on ignition of the kaolinite is close to $13.95 \%$. The JG and RF clays presented weight loss of 13.42 and $12.43 \%$, respectively, which are probably related to coordinated water, presence of clay minerals, hydroxides and organic matter.

\section{Fourier transform infrared spectroscopy (FTIR) of clays}

The FTIR spectra for bentonite clays are shown in Fig. 3. The main absorption bands with their corresponding assignments are shown in Table III. It can be observed in the spectra for both evaluated clays (Fig. 3), the presence of absorption bands at 3622 and $3441 \mathrm{~cm}^{-1}$, which can be attributed

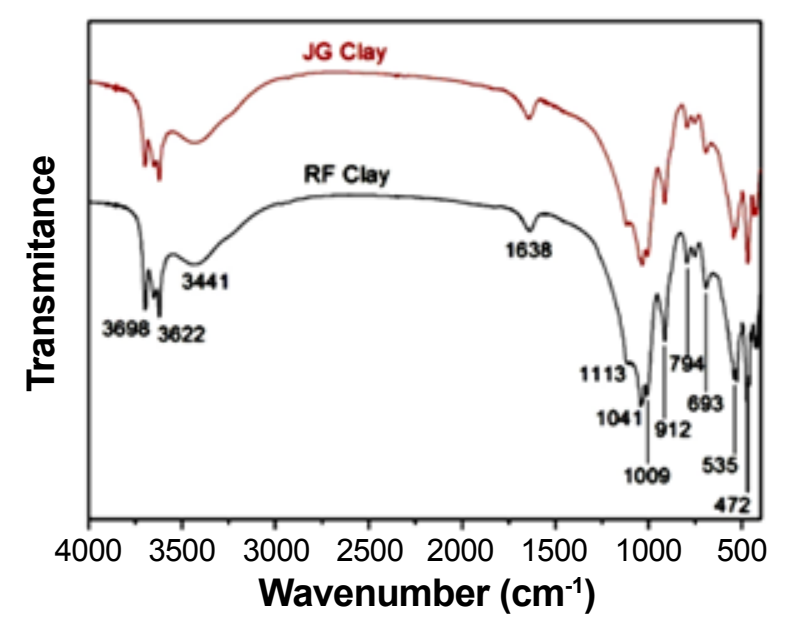

Figura 3: FTIR spectra of the studied clays.

[Figura 3: Espectros de FTIR das argilas estudadas.]

Table III - Absorption bands on the FTIR spectrum. [Tabela III - Bandas de absorção no espectro de FTIR.]

\begin{tabular}{cc}
\hline Wavenumber $\left(\mathrm{cm}^{-1}\right)$ & Attribution \\
\hline 3698 & O-H stretching \\
3622 & O-H asymmetric stretching \\
3441 & O-H symmetric stretching \\
1638 & H-O-H bending \\
1113 & Si-O stretching \\
1041 & Si-O stretching \\
912 & Octahedral sheet \\
794 & Octahedral sheet \\
693 & Si-O-Al bending \\
535 & Si-O bending \\
472 & Si-O-Si bending \\
\hline
\end{tabular}


to the asymmetric and symmetric stretching of structural hydroxyl groups, respectively. An absorption band at 1638 $\mathrm{cm}^{-1}$, attributed to the angular vibration of the $\mathrm{OH}$ group and related to the adsorbed water and the hydration water present in the clay, can also be seen in the spectra [26]. Characteristic absorption of montmorillonite clay can be observed in the region between 1113 and $1041 \mathrm{~cm}^{-1}$, characteristic of the Si-O bond, and between 912 and $794 \mathrm{~cm}^{-1}$, corresponding to the octahedral layers of the aluminosilicate. A high intensity band was observed at $472 \mathrm{~cm}^{-1}$ in the IR spectrum of the RF clay. This absorption band is also observed in the spectrum of the JG clay and can be attributed to Si-O-Si bending vibration [26]. Benites et al. [27] performed the characterization of latosols from the State of Minas Gerais by FTIR. Infrared spectra showed absorption bands characteristic of kaolinite in $3692,3656,3620,1100,1034,1008$ and $912 \mathrm{~cm}^{-1}$. The JG and RF clays showed similar absorption bands to those found in [27]. The results suggest that the clays are formed by kaolinite and montmorillonite [27]. The FTIR results are in agreement with results obtained by X-ray diffraction.

\section{Thermogravimetric analysis (TGA) of clays}

The thermogravimetric analysis is considered a simple and accurate method to evaluate the thermal stability and
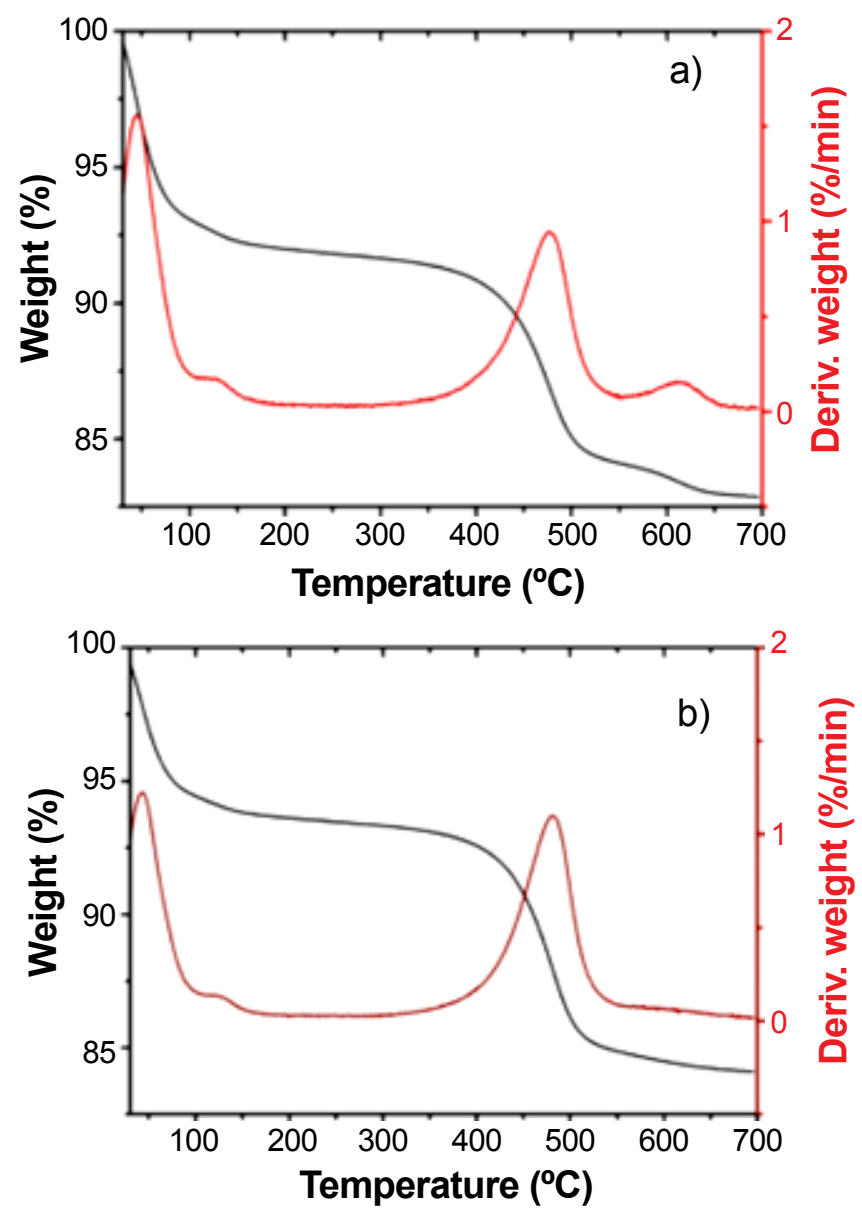

Figure 4: TG and DTG curves for JG clay (a), and RF clay (b). [Figura 4: Curvas de TG e DTG da argila JG (a) e argila RF (b).] decomposition of different materials. The TG and DTG curves for JG and RF clays are shown in Figs. $4 a$ and $4 b$, respectively. The TG and DTG curves for both clays (Fig. 4) show that the samples presented double endothermic peaks between 30 and $200{ }^{\circ} \mathrm{C}$, related to the presence of free and absorbed water. The DTG curves show the presence of two endothermic peaks in this temperature range. The first peak appears with a maximum at $45{ }^{\circ} \mathrm{C}$, while a slightly endothermic band can be seen with a maximum at $126^{\circ} \mathrm{C}$. The presence of double or triple endothermic peaks up to $200{ }^{\circ} \mathrm{C}$ is related to the presence of coordinated water to $\mathrm{Ca}^{2+}$ and $\mathrm{Mg}^{2+}$ [7]. Nevertheless, the $\mathrm{CaO}$ content for JG clay (Table II) was much higher than the other oxides of alkali and alkaline earth metals. A significant weight loss is observed in the clays in the range between 400 and 550 ${ }^{\circ} \mathrm{C}$, with maximum at $478{ }^{\circ} \mathrm{C}$, which can be attributed to the dehydroxylation of the clay minerals present in the clays. The JG clay shows a third mass loss between 550 and 650 ${ }^{\circ} \mathrm{C}$, with a maximum at $624{ }^{\circ} \mathrm{C}$, which can also be related to the decomposition of clay minerals.

\section{Cation exchange capacity (CEC) of clays}

Table IV describes the CEC of the clays under study. The CEC of the JG clay was about $41.67 \mathrm{meq} / 100 \mathrm{~g}$ while CEC of the RF clay was about $35.33 \mathrm{meq} / 100 \mathrm{~g}$. It is known that due to some limitations of methylene blue method, the values are almost always inferior to those obtained by other methods, such as ammonium acetate or barium chloride. However, the results allow a comparison of samples subjected to the same conditions [24]. Silva et al. [19] found CTC values between 56 and $64 \mathrm{meq} / 100 \mathrm{~g}$ in natural clays from the municipality of Pedra Lavada, PB.

Table IV - Cation exchange capacity of studied clays. [Tabela IV - Capacidade de troca catiônica das argilas estudadas.]

\begin{tabular}{lc}
\hline Sample & CEC $(\mathrm{meq} / 100 \mathrm{~g})$ \\
\hline JG clay & $41.67 \pm 0.76$ \\
RF clay & $35.33 \pm 1.53$ \\
\hline
\end{tabular}

\section{CONCLUSIONS}

From the studies of new occurrences of smectite clays in the municipality of Cubati, $\mathrm{PB}$, it can be concluded that the samples presented a mineral composition of montmorillonite, kaolinite and quartz. The XRD results were confirmed by FTIR. The chemical analysis of the clays showed that the samples present oxides contents similar to those found in South American bentonites.

\section{ACKNOWLEDGEMENTS}

The authors thank the Conselho Nacional para o 
Desenvolvimento Científico e Tecnológico (CNPq) and Fundação de Amparo à Pesquisa do Estado do Rio de Janeiro (FAPERJ) for financial support and the Centro de Tecnologia Mineral (CETEM) for supplying the clays. The authors also thank CAPES, for Senior Scholarship Process 3955-13-3.

\section{REFERENCES}

[1] K. Das, D. Ray, I. Banerjee, N.R. Bandyopadhyay, S. Sengupta, A.K. Mohanty, M. Misra, J. Appl. Polym. Sci. 118 (2010) 143.

[2] S.S. Ray, M. Okamoto, Prog. Polym. Sci. 28 (2003) 1539 .

[3] C. Saujanya, S. Radhakrishnan, Polymer 42 (2001) 6723.

[4] D.R. Paul, L.M. Robeson, Polymer 49 (2008) 3187.

[5] M. Alexandre, P. Dubois, Mater. Sci. Eng. 28 (2000) 1.

[6] S.M.L. Silva, P.E.R. Araújo, K.M. Ferreira, E.L. Canedo, L.H. Carvalho, C.M.O. Raposo, Polymer Eng. Sci. 49 (2009) 1696.

[7] P. Souza Santos, Ciência e Tecnologia de Argilas, $2^{\text {nd }}$ Ed., Edgar Blücher, S. Paulo (1992).

[8] L.F. Cótica, V.F. Freitas, I.A. Santos, M. Barabach, F.J. Anaissi, R.Y. Miyahara, P.W.C. Sarvezuk, Appl. Clay Sci. 51 (2011) 187.

[9] E. Teixeira-Neto, A.A. Teixeira Neto, Quím. Nova 32 (2009) 809.

[10] E.V.D.G. Líbano, L.L.Y. Visconte, E.B.A.V. Pacheco, Polímeros: Ciência Tecn. 22 (2012) 430.

[11] E.M. Araújo, T.J.A. Melo, L.N.L. Santana, G.A. Neves, H.C. Ferreira, H.L. Lira, L.H. Carvalho, M.M. A'vila Jr, M.K.G. Pontes, I.S. Araújo, Mater. Sci. Eng. B 112 (2004) 175.

[12] E.M. Araújo, R. Barbosa, A.W.B. Rodrigues, T.J.A. Melo, E.N. Ito, Mater. Sci. Eng. A 445-446 (2007) 141.

[13] R. Barbosa, E.M. Araújo, T.J.A. Melo, E.N. Ito, Mater.
Lett. 61 (2007) 2575.

[14] A.M.D. Leite, L.F. Maia, O.D. Pereira, E.M. Araújo, H.L. Lira, W.B. Castro, J. Alloy. Compoun. 495 (2010) 596.

[15] D.D.S. Morais, R. Barbosa, K.M. Medeiros, E.M. Araújo, T.J.A. Melo, Mater. Sci. Forum 727-728 (2012) 867. [16] R.R. Menezes, L.R.L. Melo, F.A.S. Fonseca, H.S. Ferreira, A.B. Martins, G.A. Neves, Rev. Eletr. Mater. Proc. 3 (2008) 36.

[17] R.R. Menezes, L.F.A. Campos, H.S. Ferreira, L.N. Marques, G.A. Neves, H.C. Ferreira, Cerâmica 55 (2009) 349.

[18] J.M.R. Costa, C.D. da Silva, I.A. da Silva, H.S. Ferreira, G.A. Neves, H.C. Ferreira, Mater. Sci. Forum 727-728 (2012) 1444.

[19] I.A. Silva, J.M.R. Costa, R.R. Menezes, H.S. Ferreira, G.A. Neves, H.C. Ferreira, REM: Rev. Escola de Minas 66 (2013) 485.

[20] I.D.S. Pereira, I.A. Silva, J.M. Cartaxo, R.R. Menezes, L.N.L. Santana, G.A. Neves, H.C. Ferreira, Cerâmica 60 (2014) 223-230.

[21] R.R. Menezes, P.M. Souto, L.N.L. Santana, G.A. Neves, R.H.G.A. Kiminami, H.C. Ferreira, Cerâmica 55 (2009) 163.

[22] ASTM C 837, "Standard Test Method for Methylene Blue Index of Clay", Annual Book of ASTM Standards, Philadelphia (2009).

[23] I.F. Leite, C.M.O. Raposo, S.M.L. Silva, Cerâmica 54 (2008) 303.

[24] S.P.A. Paz, R.S. Angélica, R.F. Neves, R. Neumann, G.M. da Costa, Cerâmica 57 (2011) 444.

[25] G.P. Souza, S.J.G. Souza, L.A.H. Terrones, J.N.F. Holanda, Cerâmica 51 (2005) 381.

[26] C. Bertagnolli, M.G.C. da Silva, Mater. Res. 15 (2012) 253.

[27] V.M. Benites, E.S. Mendonça, C.E.R. Schaefer, L. Martin Neto, Rev. Bras. Ciência Solo 23 (1999) 543.

(Rec. 21/09/2015, Rev. 14/01/2016, 15/03/2016, Ac. 15/03/2016) 